\title{
Imagined Transcultural Histories and Geographies
}

\section{Bronwyn Winter, University of Sydney}

In a globalised world, an assumption prevails that the nation has somehow lost its power to regulate our lives, being undermined by other forces, either top-down through the impact of global capitalism or bottom-up through migrations, transnational religious, ethnic or social movement communities or other transversal politics. A related idea is that 'culture' is now irrevocably hybridised and border-zoned, that we no longer live in a world of discrete, located, identifiable and historically grounded cultures but, rather, in some unstable and for-the-moment insterstitiality, a sort of cultural interlanguage that sits outside well-mapped structures of power.

Yet, just as the nation and the boundaries it sets around culture are being conceptually chased from our maps of the world, they come galloping back to reassert themselves. They do so politically, economically, legally, symbolically. Amidst all the noise of our transnationalisms, hybridities and interstitialities, the idea of what it is to be 'Australian' or 'French' or 'Filipino' or 'Asian' reaffirms itself, in mental geographies and constructed histories, as our 'imagined community' - to use Benedict Anderson's famous term (1983) — or indeed, 'imagined Other,' even if it is an imagined 'Other' that we would somehow wish to incorporate into our newly hybridised Self.

Using the notion of transcultural mappings, the articles in this special issue investigate this apparent paradox. They look at how the Self and Other have been mapped through imagined links between geography, history and cultural location. They interrogate the tension between persistent mappings of the world based on discrete national or cultural 
identities on one hand, and, on the other hand, the push to move beyond these carefully guarded borders and problematise precise notions of identity and belonging.

The idea of transculturation was coined by the Cuban anthropologist Fernando Ortiz in 1940, to describe a process of transition from one culture to another in a context of (often forced) migration, out of which new cultural formations emerged (Ortiz 1995). It has come to the fore once again, along with the idea of the transnational, within a conceptual framework that enables us to develop new interdisciplinary epistemologies of the global, the local, and the 'glocal' (for example, Wilson \& Dissanayake 1996; Grewal \& Kaplan 2000).

The concomitant development of postcolonial and crosscultural studies concepts such as the interstitial (Bhabha 1994), the hybrid (Bhabha 1994, 1998; Young 1995; Hall 2003a, 2003b), the borderlands (Anzaldúa 1987) and 'border thinking' (Mignolo 2000), have begged the question of how these notions are determined, for example: interstitial between what and what? Technically all cultures have always been hybrid, as human culture is not a reified 'thing' but a process, not static but in movement. So when we discuss border crossings and hybridities within international, postcolonial or area studies, or within comparative cultural studies, on what premises are we basing such discussions? Are we positing some mythical idea of an original cultural homogeneity, and an associated national cohesion, as a mooring from which we embark? Or are we, on the contrary, suggesting that cultural and indeed national mappings, or the discussion of an identifiable culture associated with a language, nation or region, have become superfluous and even obsolete? In which case, how can we continue to have intelligible conversations about distinctive locations of groups and individuals, constructed historically, geopolitically, culturally, socioeconomically and indeed ideologically? With all its capitalist delocalisations, globalised hybridities, and migrations of people and ideas, our world continues to be structured around the idea of the nation (or supranational region: 'Europe,' 'Asia,' and so on). Assumptions about such constructions and their impacts, even as we challenge them, thus continue to inform our analyses and debates.

In short, we continue to map the world, sociopolitically and culturally as much as physically, even as we challenge the logic of such mappings. We imagine these mappings as grounded in a historical inevitability: an always-thereness of sorts, that we 
nonetheless seek to reassert, to control anew, through our very act of mapping. Hence the paradox: mapping is an exercise in plotting, delimiting, demarcating, whether historical, geographical or symbolic: Australia (for example) is here and it came to be in this way; this is what it is and this is what it is not. The transcultural, however, like its cousin the transnational, destabilises the certainties of maps, much as Peters (or more accurately, Lambert-Gails-Peters) destabilised Mercator-or as the 'Southern' map that places the global South at the top of the globe destabilised both. The transcultural fuzzes the edges, shifts the foci, changes the shapes.

A word of explanation: the Mercator and Lambert-Gails-Peters projections are both named for their originators. Mercator was a Flemish geographer and cartographer who developed his cylindrical projection in 1569. It became a cartographical standard and was particularly useful to navigators in charting lines of constant course. Its great and much criticised disadvantage is that the scale increases from the equator to the poles, thus enlarging land masses farther from the equator and compressing those closer to the equator. This means that Africa, South America, and Australia appear much smaller than they are, and rather squat, while Europe and North America loom much bigger in comparison. The Peters projection uses an equal-area cylinder, reputed to have been developed by an Alsatian mathematician by the name of Lambert in the 1770s. James Gails proposed a Lambert-based projection in 1855, and Arno Peters presented his map in 1973 as a new invention. It quickly took on as an emblem of anti-hegemony under Peters's name, although all cylindrical-projection maps skew distances and dimensions as geographers and cartographers will readily point out. Indeed, as Juliana de Nooy points out in her article in this issue (discussed below), 'maps are relational, a projection of "there" from "here." (de Nooy, this issue).

The articles in this issue, then, look at what factors determine how different transcultural mappings occur through space and time, and on what assumptions and consenses (or questionings and discords) they are based. They investigate the operation of localised power in transnationalised constructions of place and identity, whether in asserting power over, or in aspiring to gain access to a perceived locus of power, or even in assuming an already-thereness that sits (aspirationally?) outside power relations.

Tim Laurie, in his article 'Epistemology as Politics and the Double-bind of Border Thinking: Lévi-Strauss, Mignolo, Deleuze and Guattari,' begins with the question: 'how 
can one criticise the projects of governance through knowing (episteme) linked to State projects of imperial expansion and colonialism without also according to these States the capacity to think in an orderly and consistent manner distinct from its pleasures and inclinations (epistemology)?' He explores this question through an examination of three bodies of work and approaches to discussing (post-/de-)colonial relations: Claude LéviStrauss's structuralist anthropology; Gilles Deleuze and Félix Guattari’s Althusserian and psychoanalytic poststructuralism; and Walter Mignolo's 'decolonial' and 'border' thinking. His article highlights the difficulties in providing real analytical alternatives to colonialist or otherwise dominant-class epistemologies and circuits of power. LéviStrauss, in questioning Western value systems and othering of 'primitive peoples,' nonetheless retains the authoritative voice of the Western knower. Deleuze and Guattari, in seeking to analyse the role of affect and multiplicities of often contradictory power relations, including within the Left, and in seeking to engage with gendered analysis, nonetheless remain within a masculinist framework predicated on the authoritative voice of the Western intellectual. Mignolo, in seeking simultaneously to reject naïve cultural relativist valorisations of the non-Western and to decolonise knowledge by valorising non-Western epistemologies, nonetheless glosses over differences of location and power (class and gender among others) within the 'non-West.' Moreover, in his over-reliance on a 'philology' of historical texts, Mignolo evacuates the lived experience of the historical subjects he discusses. In the end, we are left with a 'discourse on the discourse on colonialism' that ultimately fails to move us beyond an obsession with identities and locations of speakers into an analysis of the geo-historical constitution of sociopolitical relations.

Such an analysis is at the centre of Liz Rechniewski and Matthew Graves's project in 'Mapping Utopia: Cartography and Social Reform in $19^{\text {th }}$ Century Australia.' Their discussion of imagined cartographies of Australia during the first half of the nineteenth century demonstrates the clear link between these cartographies and the political idea of Australia as an 'unblemished' new land that Britain could fashion to its own blueprint as an experimental site. The cartographers discussed in the article all worked from secondhand accounts as none of them had actually visited the continent, and their 'speculative' geographies imagined Australia as a land of fertility and promise, one that would enable British dreams of social reform and egalitarianism to be realised. The very naming of different places on the maps - or proposals for names — reflects a construction of an 
exported (and utopianised) Britain, with major place names being British (named after British places or notable people), and various coats of arms and other iconographies accompanying the maps. Proposals for the containment of Indigenous peoples, even as they were granted some paternalistic respect through the preservation of some Indigenous place names, also accompanied the cartographers' projects. Clearly, mapping, and its history, are a political exercise, and nowhere more so than in these imagined British mappings of Australia that continue to inform our understanding of how our national space is constructed.

Juliana de Nooy, taking us into the twenty-first century and 'back' from Australia to Europe, discusses the mapping of the individual or collective Self through projection onto or against the Other, in her article 'The Transcultural Self: Mapping French Identity in Contemporary Australian Women's Travel Memoirs.' In this case, however, the relationship is neither colonial nor postcolonial, although the legacy of colonialism and Australia's enduring national self-conception as an outpost of Europe are clearly present in the material that de Nooy discusses. Through her discussion of memoirs by Australian women having spent some time (sometimes a mere few months) in France, de Nooy explores the idea of Frenchness not only as fetish for the protagonists of the narratives, but as a vehicle for exploring the self. For each of the women, becoming 'Almost French' or having a 'French life' (to cite two titles) is far less about acquiring knowledge or understanding of French history, politics, society, people or even language, than about a projection of female Australian selves onto a French background. Strangely, this enterprise seems not entirely dissimilar to the British projection of a social-reformist utopia onto an imagined Australia, discussed by Rechniewski and Graves. In both cases, the Other place is an imagined entity onto which one maps one's own desires: collective (or posited as such) sociopolitical desires in the BritishAustralian case, and individual feminised desires in the Australian-French case. Both are to do with the Other imagined as a backdrop onto which one projects oneself. The significant differences stem, of course, from the vastly divergent histories of BritishAustralian and Australian-French relations, and from the role of France in the feminised Anglo-world imaginary as a fantasy place, from the City of Lights to charming rural retreats, from haute couture style and cosmopolitanism to refined manners and exquisite food. France is there, in these books, for Australian consumption and female selfdiscovery. 
Consumption is also the topic of Rick Flowers and Elaine Swan's article 'Eating the Asian Other? Pedagogies of Food Multiculturalism in Australia.' Drawing on research by scholars such as Uma Narayan, Ghassan Hage and Jean Duruz, Flowers and Swan explore the issue of food consumption by white Australian elites as a superficial expression of 'multiculturalism.' Like the white Australian women living a 'French' life discussed by de Nooy, Australian elites consume a visible aspect of the Other-in this case, through eating their food-without necessarily knowing anything else about the Other either as part of the Australian demographic or as a specific cultural heritage. Going against the grain of the research, however, Flowers and Swan choose to discuss the personal story of 'Frank,' a white Australian man who married a Chinese student in the 1950s, then later, a Filipino migrant in the 1970s. He had two children with each partner. Frank also travelled a great deal in his job, to parts of South East Asia and Subsaharan Africa. He lived 'multicultural food' at a time when other white Australians were barely beginning to discover that there might be such a 'thing.'

What is particularly compelling about Flowers and Swan's account is the ordinariness of Frank's discussion of food: the crossover from potatoes to rice as staple carbohydrate, even the 'exotic' food cooked by his first and second wives, as part of the taken-forgranted, the everyday. It is only when he discusses his experience of eating 'African' food that his narrative begins to contain more 'exoticising' tropes. At the same time, the cultural specificities or culinary skills of his wives, or his emotional relationship to food, barely register a mention. Through their discussion of Frank's narrative, Flowers and Swan highlight a number of issues in need of further exploration: the relevance of gender and its interactions with culture and ethnicity; the different operation of the private and public spheres as 'places for food inter-cultural encounters and claims about identity'; and the uneven valuing of food as 'cosmopolitan capital': again, 'French' food is used as an example of high cosmopolitan capital.

The last article in this special collection, Shirlita Espinosa's 'Reading the Gendered Body in Filipino-Australian Diaspora Philanthropy,' shifts the focus from white Australian mappings onto the Other, to the Other's mappings onto Australia. It focuses on the gendering of diasporic philanthropy, through a discussion of the beauty contests at the Blacktown Fiesta Cultura (now a multicultural festival, also referred to by Flowers and Swan). The Fiesta was begun by the Filipino Community in Blacktown in 
the 1970s and has since expanded, taking on a more generic 'multicultural' flavour (although the 'Wow! Blacktown' nomenclature is a typically Filipino marketing expression). Through her exploration of how Filipino diasporic philanthropy overlaps with the feminised construction of the 'Filipino migrant' as primarily 'Filpina,' notably through the imagery of the 'mail-order bride,' Espinosa reminds us that the transcultural is also gendered, and as such, mapped onto sexualised bodies. The mapping exercise discussed by Espinosa, moreover, is that of a multiple-levelled projection. It is not only a projection of 'there' from 'here,' but also, and even more so, a projection of 'there' into 'here.' It is not only a (self-)construction of 'Asian-ness' for an Australian market - a performance of the othered 'Us' for the Australian 'them'— but also a selfreferential performance of Us for Us, to remind Us of our ethno-national duty towards 'home.' Even as who is 'Us' and who is 'Them' becomes blurred, inevitably, through the collective history and personal experience of migration, marriage and various levels of assimilation, an 'Us-ness' struggles to reinvent and reassert itself, paradoxically taking on, in this case, the very feminised construction that has been imposed from outside.

The articles in this issue show that the transcultural 'playing field' is certainly very far from being level, in the best of all cosmopolitan worlds. Transculturation is constituted first historically, including, albeit not solely, through the legacy of colonialism, and imagined geographically as a projection of 'us' onto them or an incorporation of some aspect of 'them-ness' within 'us.' The articles also show that 'them' and 'us,' even in their imagined unities and separateness, are traversed by the dialectics of, among other things, class and gender. Finally, they show us that national and cultural boundariesand the power relations they symbolise — far from being broken down, are continually reconstituting and reasserting themselves, even as they ostensibly embrace hybridisation.

\section{Reference List}

Anderson, B. 1983, Imagined Communities: Reflections on the Origin and Spread of Nationalism. Verso, London.

Anzaldúa, G. 1987, Borderlands/La frontera: The New Mestiza. Aunt Lute Books, San Francisco.

Bhabha, H. 1994, The Location of Culture. Routledge, London \& New York. 1998, 'Culture's in Between,' in Multicultural States: Rethinking Difference and Identity, (ed.) D. Bennett. Routledge, London, 29-36.

Grewal, I. \& Kaplan, C. 2000, 'Postcolonial Studies and Transnational Feminist Practices,' Jouvert: A Journal of Postcolonial Studies, vol. 5, no. 1. Online, available:

http://english.chass.ncsu.edu/jouvert/v5i1/grewal.htm [Accessed July 1, 2012]. 
Hall, S. 2003a, 'The Work of Representation,' in Representation: Cultural Representations and Signifying Practices, (ed.) S. Hall. Sage, London, 13-64.

2003b, 'The Spectacle of the "Other," in Representation: Cultural Representations and Signifying Practices, (ed.) S. Hall. Sage, London, 223-90.

Mignolo, W. 2000, Local Histories, Global Designs: Coloniality, Subaltern Knowledges, and Border Thinking. Princeton University Press, New Jersey.

Ortiz, F. [1940] 1995, Cuban Counterpoint: Tobacco and Sugar. Trans. H. de Onís. Duke University Press, Durham.

Wilson, R. \& Dissanayake, W. (eds) 1996, Global/Local: Cultural Production and the Transnational Imaginary, Duke University Press, Durham.

Young, R.J.C. 1995, Colonial Desire: Hybridity in Theory, Culture and Race. Routledge, London. 